\title{
Correction to: Identification and characterization of conserved IncRNAs in human and rat brain
}

Dan Li and Mary Qu Yang*

\section{Correction}

After publication of the original article [1], it was noticed that the Acknowledgement statement was incorrect. The original statement reads:

"This project is supported by NIHR15GM114739, FDABAA-15-00121, AEDC grant \#77138 and NIGMS P20GM103429."

However, the correct Acknowledgement statement should instead read:

"This project is partially supported by NIHR15G M114739, AEDC grant \#77138, NIGMS P20GM103429 and the Food and Drug Administration (FDA), contract No. HHSF223201510172C and HHSF223201610111C. However, the information contained herein represents the position of the author(s) and not necessarily that of the NIH and FDA."

Published online: 24 May 2018

\section{Reference}

1. Li D, Yang MQ. Identification and characterization of conserved IncRNAs in human and rat brain. BMC Bioinformatics. 2017;18(Suppl 14):489. https://doi. org/10.1186/s12859-017-1890-7.

\footnotetext{
* Correspondence: mqyang@ualr.edu

MidSouth Bioinformatics Center and Joint Bioinformatics Ph.D. Program,

University of Arkansas at Little Rock and University of Arkansas for Medical

Sciences, 2801 S. University Avenue, Little Rock, AR 72204, USA
}

(c) The Author(s). 2018 Open Access This article is distributed under the terms of the Creative Commons Attribution 4.0 International License (http://creativecommons.org/licenses/by/4.0/), which permits unrestricted use, distribution, and reproduction in any medium, provided you give appropriate credit to the original author(s) and the source, provide a link to the Creative Commons license, and indicate if changes were made. The Creative Commons Public Domain Dedication waiver (http://creativecommons.org/publicdomain/zero/1.0/) applies to the data made available in this article, unless otherwise stated. 